\title{
MOTOR INTERVENTION AND AUTISM: ONE WAY, SEVERAL DOMAINS OF EFFECTIVENESS
}

\author{
Flori Valeria ${ }^{1}$, Angeli Bruno ${ }^{2}$
}

${ }^{I}$ Terapista della neuro e psicomotricità dell'età evolutiva e Direttore dell'attività didattica del Corso di Studi in Tnpee dell'Università degli studi di Milano, sede IRCCS Eugenio Medea di Bosisio Parini (LC)

${ }^{2}$ Terapista della neuro e psicomotricità dell'età evolutiva

KEYWORDS: Autism spectrum disorder, Physical activity, Motor skill intervention, Developmental age, Childhood neuro and psychomotricity,

\section{ABSTRACT}

In the literature, a delay in the development and acquisition of motor skills is generally described in children with autism spectrum disorder, affecting between $50 \%$ and $80 \%$ of this population. In spite of this high frequency of occurrence, motor difficulties are not yet considered in the same way as the core deficits of this disorder (difficulties in social interaction, communication and behavior); addictionaly, there is not yet enough research about the efficacy of a specific intervention that can support the development of motor functions compromised in autism.

Recent findings, which support the correlation between motor domain and other areas of development (social and cognitive), together with other evidence that underline the benefits of practicing motor activities on the individual's well-being, lead us to re-evaluate the effects of motor intervention for autism.

To define the salient points of this kind of intervention, with particular attention to rehabilitation practice, a literature search was carried out on four different databases, which sifted through 602 bibliographic citations and found 10 studies that were able to meet the set research purposes.

This review showed that physical activity in autistic children not only improves motor performance, but also plays an important role in the social, cognitive and behavioural development, as well as helping to reduce some secondary or associated symptoms, such as stereotypies or sleep disorders.

\section{INTRODUCTION}

Autism Spectrum Disorder (ASD) is an early-onset neurodevelopmental condition characterised by a significant impairment in social interaction and communication and by the presence of restricted interests and repetitive and stereotyped behaviour. Its frequency is around $1 \%$ of the population and its symptoms have a significant impact on several areas of an individual's life (American Psychiatric Association, 2013) .

In addition to the main symptoms, the literature also reports the possibility of cognitive, linguistic and sensory impairments (Casartelli \& Molteni, 2014) as well as internal disorders (epilepsy, gastro-intestinal problems, sleep disorders, obesity).

From this complex and varied clinical picture, it is already clear that an integrated and effective treatment approach, covering all developmental compromised needs, is indispensable (Lai, et al., 2020).

Nowadays, pharmacological intervention can be used to reduce secondary or associated symptoms, but there is no approved medication that can directly decrease the central deficits of this disorder. (Lai, et al., 2020), (Lai, et al., 2014) Therefore, the definition and early implementation of a rehabilitation programme is crucial to address this disorder (Rogers, et al., 2014) . An in-depth knowledge of the autism's symptoms is fundamental as a guide to planning the intervention project. Given all these assumptions, the "motor cognition" hypothesis, recently put forward by the neurosciences, becomes relevant. This idea argues that the motor system is not only involved in the control and execution of movement, but can also mediate, in a direct and pre-reflective way, the adaptation and understanding of our and others' behaviour. (Casartelli \& Chiamulera, 2016), (Gallese, et al., 2009) .

This correlation between motor and social domains allows to design an improved motor intervention for children with autism, that can support both the development of impaired motor skills and social abilities (Casartelli, et al., 2016).

Indeed, $50 \%-80 \%$ of people with autism have difficulties in developing and acquiring motor skills (Sanchack, et al., 2016), (Hilton, et al., 2012) and these difficulties, according to some authors, tend to translate over time into a significant decrease in physical activity, which increases the risk of obesity and clinical conditions associated with overweight (McCoy, et al., 2016)

Moreover, motor activities seem to be positively associated with increased cognitive performance in autistic individuals (Kramer \& Erickson, 2007) (Russo, et al., 2007) .

Despite these evidence in clinical practice, there is still little attention on motor intervention, compared to other types of autism treatment (Bremer, et al., 2015), (Casartelli, et al., 2016) .

The main aim of this study is to carry out a literature search to assess the effects and benefits of physical activity and motor intervention on autistic children. Specifically, we are going to consider all the possible "outcomes" of these interventions.

Secondly, time frames and methods most related to the success of this approach will be considered. 


\section{METHODS AND MATERIALS}

Search strategy

The literature search was conducted through four databases: primarily PubMed, secondarily Embase, Cinahl and Cochrane. Key words such as "physical activity", "exercise", "performance”, "motor skill”, "motor approach", "motor intervention" were used, combined through the Boolean operator "AND" with "autism" or "autism spectrum disorder".

The terms that produced the most appropriate and numerous results in PubMed were re-purposed in the other databases, after verifying the adequacy.

\section{Selection criteria}

The studies were chosen according to the following criteria: (1) Propensity based on the evidence pyramid's hierarchy for: meta-analyses, systematic reviews, followed by randomised control trials, pilot studies and finally clinical studies. (2) Target population: studies including only subjects diagnosed with autism spectrum disorder or synonyms (old diagnostic classifications) with average age $0-18$ years. (3) Type of intervention: studies that primarily focus on motor exercises or physical activity. (4) Studies published since 2015.

\section{Exclusion criteria:}

(1) Clinical studies with less than 20 participants. (2) Studies with other populations out of the autistic one. (3) Studies including subjects with an overall mean age above 18 years. (4) Studies with year of publication $<2015$. (5) Studies including only adolescents' participants.

\section{Screening process}

To determine which articles from the initial keyword search should have been included in the study, a fourstage screening was conducted. In stage 1, all records found were entered into the Mendeley software (version 1.19.4), which automatically removed any duplicate citations. In stage 2 , the title of each study was screened, looking for a match between it and the keywords used in the search. When the title seemed relevant, the article was selected to be added to a new collection. This was followed by stage 3 , where all the abstracts of the newly saved articles were examined. When the abstracts did not contain enough information about the topic (motor treatment and autism) or all the inclusion criteria, the articles were immediately excluded. In stage 4, the remaining articles were read in their entirety to check their adequacy to the pre-established selection/exclusion criteria.

\section{Data extraction process}

In order to extract the data of specific interest, the information of each study was divided into 5 main categories: "authors and date”, "type of study", "objectives", "participants", "method of data collection and analysis/intervention" and "findings and notes of interest". In this discussion we chose to combine "method of data collection and analysis" with "intervention" to better balance the amount of information within the data extraction table. Indeed, in the systematic reviews chosen data collection and analysis are very well defined while there is less information regarding the specific intervention methodology.

On the other hand, all the other types of studies analysed focus mainly on the conduction of the treatment.

\begin{tabular}{|l|l|l|}
\hline Banca dati & \multicolumn{1}{|c}{ Strategia di ricerca } & \multicolumn{1}{c}{ Limiti } \\
\hline PubMed & "autism spectrum disorder" AND "physical activity" & $\begin{array}{l}\text { Human, English, last 5 years and } \\
\text { child (birth-18 years) }\end{array}$ \\
\hline PubMed & "autism spectrum disorder" AND "exercise" & $\begin{array}{l}\text { Human, English, last } 5 \text { years and } \\
\text { child (birth-18 years) }\end{array}$ \\
\hline PubMed & "autism spectrum disorder" AND "performance" & $\begin{array}{l}\text { Human, English, last 5 years, } \\
\text { review and child (birth-18 years) }\end{array}$ \\
\hline PubMed & "autism spectrum disorder" AND "motor skill" & $\begin{array}{l}\text { Human, English, last 5 years, } \\
\text { and child (birth-18 years) }\end{array}$ \\
\hline PubMed & "autism spectrum disorder" AND "motor intervention" & / \\
\hline Embase & autism"+ all synonyms AND "physical activity"+ all synonyms & $\begin{array}{l}\text { Embase not medline, 2018-2020, } \\
\text { child* OR preschool*OR school** }\end{array}$ \\
\hline Embase & "autism"+ all synonyms AND "exercise"+ all synonyms & $\begin{array}{l}\text { Embase not medline, 2017-2020, } \\
\text { child* OR preschool* OR school** }\end{array}$ \\
\hline Cinahl (PICO) & "autism"(P) AND "physical activity"(I) & $\begin{array}{l}\text { Human, apply equivalent, } \\
\text { english, 2016-2020, all child }\end{array}$ \\
\hline Cinahl (PICO) & "autism"(P) AND "exercise"(I) & $\begin{array}{l}\text { Human, apply equivalent, } \\
\text { english, 2016-2020, all child }\end{array}$ \\
\hline Cochrane & "autism" AND "physical activity" & / \\
\hline Cochrane & "autism" AND "exercise" & / \\
\hline
\end{tabular}

Fig. 1 - Bibliographic search strategy table.

Definition of motor intervention/physical activity To better understand the reasons for favouring one study over another, it is good practice to define what is meant by motor intervention and physical activity. They refer to planned games, activities, sports and exercises involving a significant expenditure of energy, carried out in family, school or community setting, to improve physical and mental health (World Health Organization, 2010)

In the literature the attention to these aspects is often pay to different experimental designs related to specific sport practices and their positive impact on autism (e.g.: karate and autism). In this review these studies have been excluded, in favour of searches that summarise in a more exhaustive, comparable and reliable way the relationship between sport and autism.

\section{RESULTS}

Figure 1 summarises in table form the search strategy illustrated in the previous paragraph; it highlights the keywords, boundaries and databases used to identify the records.

This chart summarises in schematic form the different stages of the search conducted on the identified records.

The keyword database search produced 602 records (identification stage). By entering them into the Mendely software, which automatically excludes duplicates, the number of these citations was reduced to 502 . Subsequently, through a careful reading of the title and the abstract, 488 articles were excluded as irrelevant or not meeting the selection/exclusion criteria (screening stage). The remaining 14 articles were examined entirely: 2 were excluded because of their lower scientific evidence class compared to other two selected studies dealing with the same topic; 1 was deleted because of the low number of participants and another was discarded because it did not include any reference to specific outcome indicators (eligibility stage). In conclusion, the discussion of the results will refer to 10 articles (inclusion stage). 


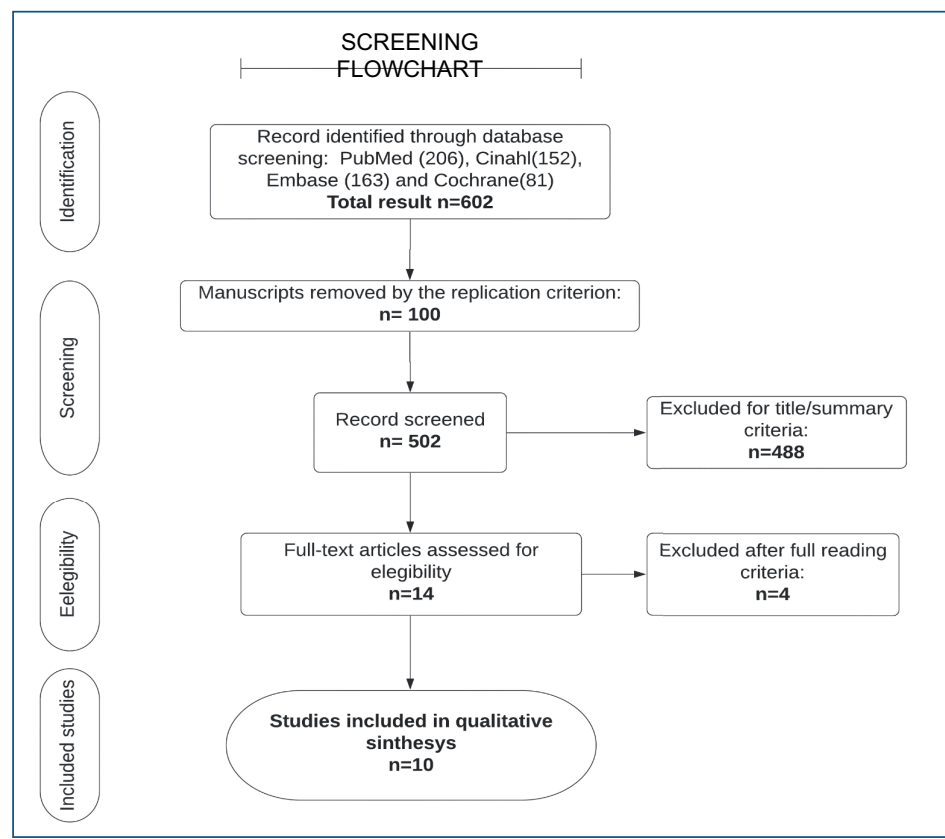

Fig. 2 - Flow chart of the literature screening process.

To identify salient data to meet the research purposes, the data extraction process was organised in a summary table, presented below.

\section{DISCUSSION}

The primary purpose of this review was to examine the effects and benefits of a motor approach in autistic children of developmental age; secondly, to define the methods and time frames most associated with the success of this intervention, both in terms of functional and global outcome.

The results of this research are in line with recent evidence that emphasises the interconnection between the different functional domains of autistic subjects (Casartelli, et al., 2016) , (Kramer \& Erickson, 2007) , supporting the idea that a change in one area, such as in the motor one, can produce a cascade effect at the level of other functions such as the social, behavioural, cognitive ones.

In the following paragraphs the emerging evidence will be discussed and organised in relation to the different outcome areas.

\section{Motor on motor}

The motor outcome was considered by 5 studies, compared to the 10 included in this paper.

From all of these, as also reported in other works (Sam, et al., 2015), motor intervention in children with autism improves their motor skills and decreases their deficits in acquiring and using them.

This conclusion is based on data from a total of approximately 2383 autistic children, a number which confers a certain degree of reliability to this result.

Specifically, it seems that depending on the type of physical activity proposed, there is an increase in certain motor skills compared to others. (Ruggeri, et al., 2020), (Ketcheson, et al., 2017). .

In particular, horse riding seems to be associated with improved balance, general coordination and manipulative skills. (Ruggeri, et al., 2020) .

While a structured intervention through motor skill

Data extraction table

\begin{tabular}{|c|c|c|c|c|c|}
\hline $\begin{array}{l}\text { Authors } \\
\text { and date }\end{array}$ & Type of study & Objectives & Participants & $\begin{array}{l}\text { Method of data } \\
\text { collection and analysis/ } \\
\text { intervention }\end{array}$ & Results and notes of interest \\
\hline $\begin{array}{l}\text { (Huang, et } \\
\text { al., 2020) }\end{array}$ & Meta-analysis & $\begin{array}{l}\text { Assessing } \\
\text { the effects } \\
\text { of a physical } \\
\text { intervention on } \\
\text { children and } \\
\text { adolescents } \\
\text { with autism. } \\
\text { In particular, } \\
\text { the study tests } \\
\text { the positive } \\
\text { correlations of } \\
\text { physical activity } \\
\text { with social } \\
\text { interaction, } \\
\text { communication, } \\
\text { stereotypical } \\
\text { behaviour, } \\
\text { sporting ability } \\
\text { and the degree } \\
\text { of autism. }\end{array}$ & $\begin{array}{l}197 \text { autistic } \\
\text { subjects } \\
\text { divided into } \\
\text { case-controls, } \\
\text { examined for the } \\
\text { associations of } \\
\text { physical activity } \\
\text { with the social } \\
\text { interaction } \\
\text { domain; } \\
240 \text { for the } \\
\text { communication } \\
\text { area; } 146 \text { for } \\
\text { the effects on } \\
\text { stereotypies; } \\
172 \text { for the } \\
\text { motor skills' } \\
\text { improvement; } \\
107 \text { to } \\
\text { investigate the } \\
\text { repercussions of } \\
\text { the intervention } \\
\text { on the degree of } \\
\text { autism. }\end{array}$ & $\begin{array}{l}\text { The authors search } \\
\text { both 'commonly used' } \\
\text { databases (e.g. PubMed) } \\
\text { and Chinese databases } \\
\text { such as CNKI or } \\
\text { WanFang data. They } \\
\text { selected } 4 \text { articles } \\
\text { in Chinese and } 8 \text { in } \\
\text { English. The cycle for } \\
\text { the interventions ranges } \\
\text { between } 4 \text { and } 24 \text { weeks } \\
\text { with an average duration } \\
\text { of } 40-90 \text { minutes per } \\
\text { session. Physical activity } \\
\text { is meant as any task that } \\
\text { burns energy and activates } \\
\text { muscle contraction. }\end{array}$ & $\begin{array}{l}\text { The analysis of the data shows that physical } \\
\text { activity in the autistic population (children/ } \\
\text { adolescents) promotes and improves social } \\
\text { interaction, the area of communication, the } \\
\text { development of motor skills and reduces the } \\
\text { degree of autistic symptoms. } \\
\text { Specifically, in group motor activities, autistic } \\
\text { children find the opportunity to experience } \\
\text { sociality, not necessarily mediated by } \\
\text { language. } \\
\text { The activities must last at least } 4-24 \text { weeks } \\
\text { with a frequency of } 4-13 \text { meetings per week } \\
\text { to bring about a statistically significant } \\
\text { improvement in the social domain. While to } \\
\text { implement their motor skills significantly a } 12 \\
\text { weeklong activity is needed: } 45-75 \text { minutes } \\
\text { once or twice a week. } \\
\text { In addition, motor activity } 5-7 \text { times a } \\
\text { week, for about } 90 \text { minutes, shows a general } \\
\text { decrease in autistic traits. } \\
\text { The heterogeneity of studies has produced } \\
\text { contradictory results regarding stereotyped } \\
\text { movements, although, in general, continuous } \\
\text { and frequent physical activity brings many } \\
\text { benefits. } \\
\text { The general limitations of the meta-analysis } \\
\text { concern the precise definition of the type of } \\
\text { rehabilitation activity and intervention that the } \\
\text { subjects carried out. }\end{array}$ \\
\hline
\end{tabular}




\begin{tabular}{|c|c|c|c|c|c|}
\hline $\begin{array}{l}\text { (Ruggeri, et } \\
\text { al., 2020) }\end{array}$ & $\begin{array}{c}\text { Systematic } \\
\text { review }\end{array}$ & $\begin{array}{l}\text { Evaluate } \\
\text { the effect } \\
\text { of a motor } \\
\text { intervention/ } \\
\text { physical activity } \\
\text { on the motor } \\
\text { skills of people } \\
\text { with autism } \\
\text { (learning motor } \\
\text { strategies, } \\
\text { acquisition of } \\
\text { motor skills, } \\
\text { maintenance } \\
\text { of skills over } \\
\text { time and } \\
\text { generalisation } \\
\text { to the adaptive } \\
\text { context). }\end{array}$ & $\begin{array}{l}1173 \text { children } \\
\text { with autistic } \\
\text { spectrum } \\
\text { disorder in a } \\
\text { range age from } 3 \\
\text { to } 19 \text { years. } \\
83 \% \text { of the } \\
\text { subjects } \\
\text { surveyed were } \\
\text { male. } \\
82 \text { typically } \\
\text { developing } \\
\text { children used as } \\
\text { a control group } \\
\text { (range 6-12 } \\
\text { years of age). }\end{array}$ & $\begin{array}{l}\text { From } 6 \text { databases, sifting } \\
\text { through } 7972 \text { results, } 41 \\
\text { studies were included in } \\
\text { the search. The authors } \\
\text { follow the "PRISMA" } \\
\text { guidelines. A quantitative } \\
\text { analysis of the data was } \\
\text { not carried out due to the } \\
\text { excessive heterogeneity } \\
\text { of the studies. } \\
\text { The types of intervention } \\
\text { were divided into } 6 \\
\text { groups: } \\
\text { 1. motor activities } \\
\text { (n=9), } 2 \text {. motor skills } \\
\text { intervention (n=7), } 3 \text {. } \\
\text { hippotera pia ( } \mathrm{n}=6), 4 \text {. } \\
\text { water intervention ( } \mathrm{n}=5 \text { ), } \\
\text { 5. motor games (n=4) } \\
\text { and } 6 \text {. physical education } \\
(\mathrm{n}=6) \text { which were then } \\
\text { brought back to } 2 \text { macro } \\
\text { areas: motor competence } \\
(\mathrm{n}=7 \text { ) and motor skills } \\
\text { acquisition ( } \mathrm{n}=34) \text {. }\end{array}$ & $\begin{array}{l}\text { The results show that each type of intervention } \\
\text { contributes differently to the acquisition of } \\
\text { certain motor skills. } \\
\text { Furthermore, it is shown that the use of visual } \\
\text { material to support the teaching of gestures } \\
\text { and actions, opposed to verbal teaching alone, } \\
\text { is more conducive to learning motor skills in } \\
\text { individuals with autism. } \\
\text { The operator variable in relation to "who } \\
\text { teaches", according to the data, does not } \\
\text { contribute significantly to changing the } \\
\text { outcome of the intervention. } \\
\text { There are some limitations regarding the level } \\
\text { of evidence of the individual studies and the } \\
\text { methodology with which they are carried out, } \\
\text { as there is a lack of a methodological protocol } \\
\text { and a shared measurement of the outcome, } \\
\text { which do not allow a precise definition of the } \\
\text { limits and characteristics for a gold standard } \\
\text { intervention. }\end{array}$ \\
\hline $\begin{array}{c}\text { (Ferreira, et } \\
\text { al., 2019) }\end{array}$ & Meta-analysis & $\begin{array}{l}\text { To evaluate } \\
\text { what effect } \\
\text { physical activity } \\
\text { has on the } \\
\text { stereotyped } \\
\text { behaviour of } \\
\text { autistic subjects. }\end{array}$ & $\begin{array}{l}129 \text { children } \\
\text { diagnosed with } \\
\text { autism spectrum } \\
\text { disorder }(115 \\
\text { boys and } 14 \\
\text { girls) with a } \\
\text { mean age of } \\
8.93 \pm 1.69 \text { years. }\end{array}$ & $\begin{array}{l}\text { The authors use the } \\
\text { 'PRISMA' guidelines } \\
\text { to guide the search and } \\
\text { screening of articles. } \\
\text { Furthermore, they use } \\
\text { the "TREND statement" } \\
\text { with a minimum criterion } \\
\text { of } 50 \% \text { QoI to select } \\
\text { quantitatively suitable } \\
\text { studies for meta-analysis. } \\
\text { Thus, } 8 \text { studies were } \\
\text { included in the meta- } \\
\text { analysis. } \\
\text { These include motor } \\
\text { interventions with } \\
\text { varying intensity, duration } \\
\text { from } 8 \text { to } 48 \text { weeks and } \\
\text { frequency of } 3 \text { sessions } \\
\text { per week. }\end{array}$ & $\begin{array}{l}\text { The review shows that motor activity } \\
\text { significantly reduces the number of } \\
\text { stereotypical movements in autistic subjects, } \\
\text { with a positive association between the } \\
\text { intensity of motor activity and the reduction of } \\
\text { stereotypies. } \\
\text { One of the included studies also shows that } \\
\text { even quiet aerobic activity ( } 50-60 \% \text { maximum } \\
\text { age-calculated heart rate) can lead stereotyped } \\
\text { behaviour. } \\
\text { The limitations of this review are related to the } \\
\text { temporal definition of the results. } \\
\text { More data are needed to clarify whether the } \\
\text { effect of the improvement persists (it seems } \\
40 \text { to } 120 \text { minutes) and which type of activity, } \\
\text { frequency and duration of activity leads to } \\
\text { greater effectiveness. }\end{array}$ \\
\hline $\begin{array}{l}\text { (Tse, et al., } \\
\text { 2019) }\end{array}$ & $\begin{array}{l}\text { Study } \\
\text { randomization- } \\
\text { controlled trial }\end{array}$ & $\begin{array}{l}\text { Assessing } \\
\text { the effect of } \\
\text { physical activity } \\
\text { on executive } \\
\text { functions and } \\
\text { sleep in children } \\
\text { with autism }\end{array}$ & $\begin{array}{l}40 \text { autistic } \\
\text { subjects with } \\
\text { a mean age } \\
\text { of } 9.95 \text { years, } \\
\text { randomly } \\
\text { assigned to } 2 \\
\text { groups (activity } \\
\text { and control } \\
\text { group). }\end{array}$ & $\begin{array}{l}\text { The subjects assigned to } \\
\text { the intervention group had } \\
\text { to perform } 24 \text { basketball } \\
\text { sessions (twice a week } \\
\text { for } 45 \text { minutes each), } \\
\text { divided into } 10 \text { minutes of } \\
\text { warming up, } 30 \text { minutes } \\
\text { of playing and } 5 \text { minutes } \\
\text { of stretching. } \\
\text { Conversely, the control } \\
\text { group was not required } \\
\text { to perform any specific } \\
\text { physical activity. } \\
\text { Sleep data were collected } \\
\text { as a function of four } \\
\text { parameters, while } \\
\text { inhibition and working } \\
\text { memory were examined } \\
\text { for executive functions } \\
\text { both before and after } \\
\text { the administration of } \\
\text { the intervention in both } \\
\text { groups. }\end{array}$ & $\begin{array}{l}\text { As hypothesised by the authors, motor } \\
\text { intervention brings significant benefits for } \\
\text { children with autism in both the area of sleep } \\
\text { and executive functions. } \\
\text { In particular, regarding sleep, there is an } \\
\text { increase in the duration of sleep compared to } \\
\text { the overall time spent in bed, the time needed } \\
\text { to fall asleep decreases and there is less } \\
\text { latency in the awakening phase. } \\
\text { For executive functions, on the other hand, } \\
\text { there are improvements only regarding } \\
\text { inhibition, which is related to activities that } \\
\text { specifically required controlling your own } \\
\text { body and implementing a specific sequence to } \\
\text { achieve a goal (inhibitory skills). } \\
\text { The authors hypothesise a possible } \\
\text { improvement of self-regulating abilities, } \\
\text { which were not measured. } \\
\text { The lack of improvement in working memory } \\
\text { was instead attributed to the simplicity of the } \\
\text { requests, which did not allow specific work on } \\
\text { the function. }\end{array}$ \\
\hline
\end{tabular}




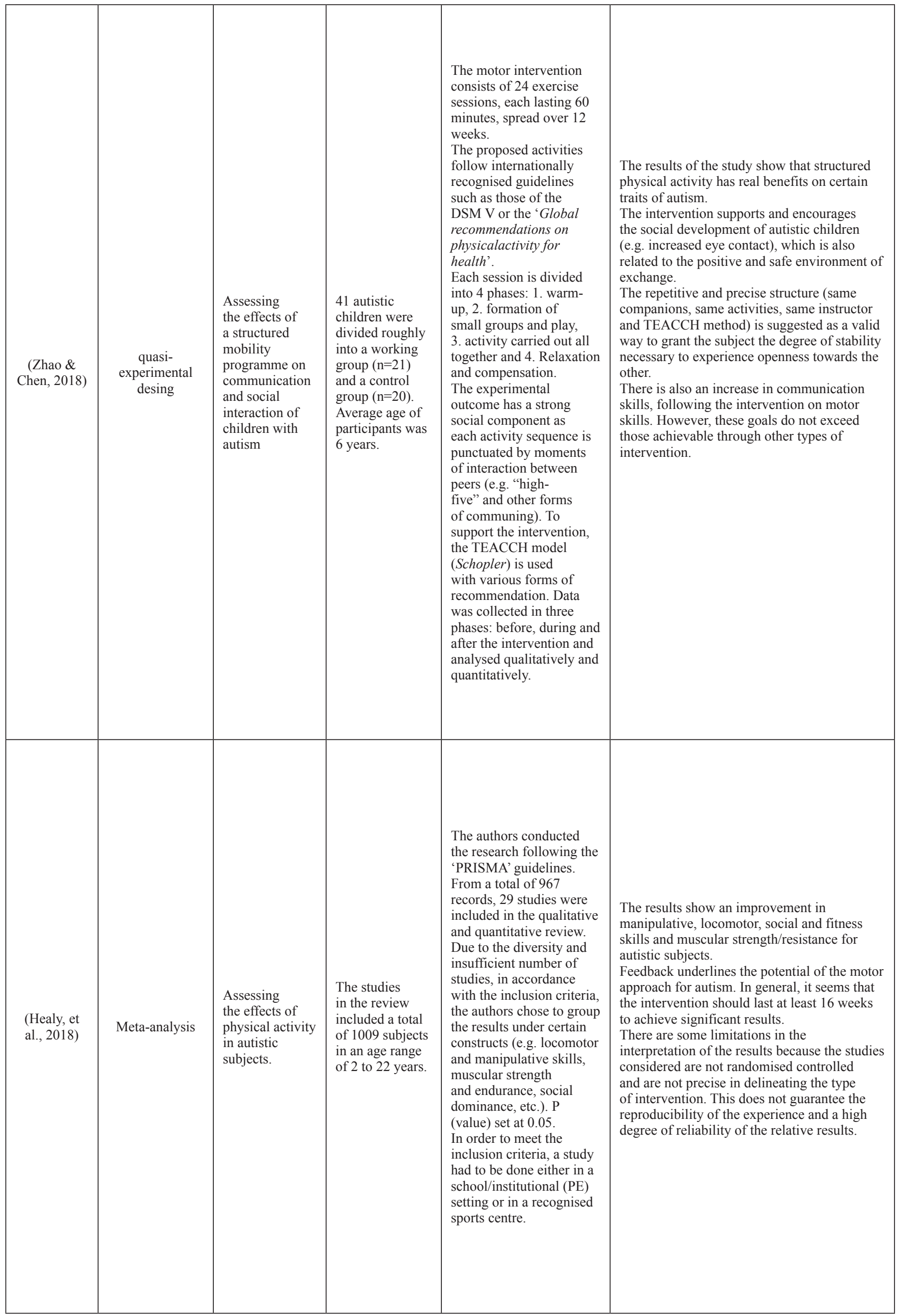




\begin{tabular}{|c|c|c|c|c|c|}
\hline $\begin{array}{l}\text { (Toscano, et } \\
\text { al., 2018) }\end{array}$ & $\begin{array}{c}\text { randomized } \\
\text { controlled trial }\end{array}$ & $\begin{array}{l}\text { Assessing } \\
\text { the effects of } \\
\text { a motorised } \\
\text { intervention on } \\
\text { the metabolism } \\
\text { of individuals } \\
\text { with autism, } \\
\text { their disruptive } \\
\text { traits and their } \\
\text { quality of life }\end{array}$ & $\begin{array}{l}64 \text { autistic } \\
\text { children divided } \\
\text { roughly into } 46 \\
\text { cases and } 18 \\
\text { controls, ranging } \\
\text { in age from } 6 \text { to } \\
12 \text { years. } \\
\text { In particular, } 9 \\
\text { children were } \\
\text { diagnosed with } \\
\text { 'Asperger's } \\
\text { syndrome', } 43 \\
\text { were diagnosed } \\
\text { as autistic, and } \\
12 \text { others met } \\
\text { the criteria for } \\
\text { the category } \\
\text { 'developmental } \\
\text { disorders } \\
\text { without } \\
\text { specification'. }\end{array}$ & $\begin{array}{l}\text { To cushion the effects of } \\
\text { exclusion and withdrawal } \\
\text { of some participants } \\
\text { from the intervention } \\
\text { group, the authors of } \\
\text { this study defined a } \\
\text { causal allocation with an } \\
\text { unbalanced ratio of } 1 \text { to } \\
3 \text { in favour of the case } \\
\text { group. } \\
\text { The children in the } \\
\text { experimental group } \\
\text { undertook a } 48 \text {-week } \\
\text { physical activity } \\
\text { programme, including } \\
\text { basic coordination and } \\
\text { strength exercises. } \\
\text { The programme was } \\
\text { divided into } 96 \text { sessions } \\
\text { of } 40 \text { minutes ( } 2 \text { sessions } \\
\text { per week), to be carried } \\
\text { out in a small group } \\
\text { of children (max. } 3 \text { ): } 5 \\
\text { minutes preparation, } 30 \\
\text { minutes activity and } 5 \\
\text { minutes relaxation, in } \\
\text { which the caregivers also } \\
\text { participated. } \\
\text { The outcome indices } \\
\text { are collected through } \\
\text { biological tests } \\
\text { and behavioural } \\
\text { questionnaires. }\end{array}$ & $\begin{array}{l}\text { The results show that this type of motor } \\
\text { intervention helps to improve certain aspects } \\
\text { of the metabolic profile, reduces the traits of } \\
\text { the disorder and promotes a more positive } \\
\text { perception of life quality. } \\
\text { In particular, this treatment produced: } \\
\text { - An increase in HDL-C and a } \\
\text { decrease in LDL-C and general } \\
\text { cholesterol levels; } \\
\text { A reduction in stereotyped } \\
\text { behaviour and an increase in verbal } \\
\text { and non-verbal communication } \\
\text { skills; } \\
\text { A positive change in parents' } \\
\text { perception of their child's autistic } \\
\text { traits and quality of life. }\end{array}$ \\
\hline $\begin{array}{l}\text { (Ketcheson, } \\
\text { et al., 2017) }\end{array}$ & Pilot study & $\begin{array}{l}\text { Measuring } \\
\text { the effects } \\
\text { of intensive } \\
\text { motivational } \\
\text { treatment in } \\
\text { autistic children } \\
\text { with regard to } \\
\text { their level of } \\
\text { motor skills, } \\
\text { physical activity } \\
\text { and degree of } \\
\text { socialisation. }\end{array}$ & $\begin{array}{l}20 \text { autistic } \\
\text { subjects (11 } \\
\text { cases and } 9 \\
\text { controls) aged } \\
\text { between } 4 \text { and } 6 \\
\text { years. }\end{array}$ & $\begin{array}{l}\text { The instruments mainly } \\
\text { used to monitor changes } \\
\text { and the effectiveness of } \\
\text { the motor programme are } \\
\text { TGDM-2 (Urlich et. al), } \\
\text { a triaxial accelerometer } \\
\text { and, only for the case } \\
\text { group, POPE (Dean and } \\
\text { Chang). } \\
\text { The intervention group } \\
\text { followed a motor } \\
\text { programme of } 4 / 5 \text { days } \\
\text { per week for a total of } 8 \\
\text { weeks. } \\
\text { The motor activity session } \\
\text { is carried out in a } 1: 1 \\
\text { teacher-child ratio. } \\
\text { The proposal of activities } \\
\text { follows the PCRT method } \\
\text { (“Classroom Pivotal } \\
\text { Response Teaching") } \\
\text { of Aubyn C. Stahmer, a } \\
\text { behavioural model carried } \\
\text { out in a natural setting. }\end{array}$ & $\begin{array}{l}\text { The results show significant differences in } \\
\text { the experimental group ( } \mathrm{p} \text { value }=0.01 \text { ) in the } \\
\text { locomotor sphere (object control and general } \\
\text { gross motor quotient). } \\
\text { The improvement occurs and seems to settle } \\
\text { after about } 4 \text { weeks of intervention; for the } \\
\text { "control of the object" effective changes are } \\
\text { recorded only between the 4th and 8th week, } \\
\text { perhaps in relation to the greater complexity } \\
\text { of the task. } \\
\text { At the level of the social area, there is a } \\
\text { reduction in the time spent (p value = 0.05) by } \\
\text { each subject in solitary play and this openness } \\
\text { can be associated with an improvement in } \\
\text { motor skills in relation to the emerging ability } \\
\text { to explore the environment. }\end{array}$ \\
\hline $\begin{array}{l}\text { (Bremer, et } \\
\text { al., 2016) }\end{array}$ & $\begin{array}{l}\text { Systematic } \\
\text { review }\end{array}$ & $\begin{array}{l}\text { Evaluating } \\
\text { the effects } \\
\text { of physical } \\
\text { exercise } \\
\text { on mental } \\
\text { behaviour in } \\
\text { autistic subjects. }\end{array}$ & $\begin{array}{l}\text { Autistic } \\
\text { individuals } \\
\text { under } 16 \text { years } \\
\text { of age }\end{array}$ & $\begin{array}{l}\text { From } 124 \text { records through } \\
\text { a selection process, } 13 \\
\text { limbs were included for } \\
\text { the review. } \\
\text { Due to the heterogeneity } \\
\text { of treatments and } \\
\text { outcomes, a quantitative } \\
\text { analysis of the data was } \\
\text { not performed. } \\
\text { Elected studies include } 5 \\
\text { types of exercise: jogging, } \\
\text { horseback riding, martial } \\
\text { arts, yoga, dancing and } \\
\text { swimming. } \\
\text { Outcomes relating to } \\
\text { stereotyped behaviour, } \\
\text { attention and cognition } \\
\text { and social-emotional } \\
\text { behaviour are assessed. }\end{array}$ & $\begin{array}{l}\text { Despite the poor definition of the method and } \\
\text { the consequent variability of the results, the } \\
\text { review shows that motor exercises can be used } \\
\text { as a behavioural treatment for autistic people; } \\
\text { in particular the practice of martial arts or } \\
\text { equitation implies greater benefits than other } \\
\text { exercises. } \\
\text { The poor definition of the method does not } \\
\text { allow the definition of precise time frames; } \\
\text { it seems that stereotypies improve after } 15 \\
\text { minutes of running; martial arts seem to be } \\
\text { effective with } 56 \text { h of practice. } \\
\text { There is also a lack of follow-up data. } \\
\text { However, the authors point to certain } \\
\text { associations: jogging, horse riding and martial } \\
\text { arts have positive effects on the reduction of } \\
\text { autistic stereotypes; yoga, dancing, martial } \\
\text { arts, horse riding and swimming have positive } \\
\text { effects on social-emotional skills, while } \\
\text { jogging has positive effects on attentional } \\
\text { skills and general cognition. }\end{array}$ \\
\hline
\end{tabular}




\begin{tabular}{|c|c|c|c|c|c|}
\hline $\begin{array}{c}\text { (Bremer, et } \\
\text { al., 2015) }\end{array}$ & Pilot study & $\begin{array}{l}\text { To evaluate } \\
\text { the effect } \\
\text { of a motor } \\
\text { intervention in } \\
\text { autistic children } \\
\text { and to study } \\
\text { the outcome in } \\
\text { terms of activity } \\
\text { intensity. }\end{array}$ & $\begin{array}{l}9 \text { autistic } \\
\text { children aged } 4 \\
\text { years ( } 5 \text { cases } \\
\text { and } 4 \text { controls). }\end{array}$ & $\begin{array}{l}\text { The experimental } \\
\text { intervention lasts } 12 \\
\text { weeks, } 1 \text { hour per week } \\
\text { and works on motor and } \\
\text { mental skills. } \\
\text { The control group in } \\
\text { the first phase does not } \\
\text { participate in any type } \\
\text { of intervention while } \\
\text { in the second phase } \\
\text { they participate in an } \\
\text { intervention of different } \\
\text { intensity (for } 12 \text { weeks } 1 \mathrm{~h} \\
\text { per week versus } 6 \text { weeks } \\
2 \mathrm{~h} \text { per week). }\end{array}$ & $\begin{array}{l}\text { The results show that the motor intervention } \\
\text { produces significant differences in the motor } \\
\text { area but not in the social or behavioural one. } \\
\text { The intensity at which it is administered does } \\
\text { not change the results. } \\
\text { Improvements in motor skills persisted at } \\
\text { follow-up (after } 6 \text { weeks). } \\
\text { General limitations of the study are the } \\
\text { small sample size and the duration of the } \\
\text { intervention. }\end{array}$ \\
\hline
\end{tabular}

Tab. 1 - Data extraction table for the analysis of articles elected for review.

exercises promotes control over objects and the acquisition and use of new movement patterns. (Ketcheson, et al., 2017) . Exercises in water are more significant when the subjects lack some of the prerequisites necessary for motor development, such as muscle strength or joint flexibility. (Ruggeri, et al., 2020). .

It is difficult to define the type of specific activity as in the article the method is generally not described in a way that makes it reproducible (methodological limitation).

Treatments usually produce significant improvements if they last at least 12 weeks, 45-75 minutes per session and are practised 1-2 times per week. However, there is still no unanimous agreement on the treatment's duration.

The study by Bremer and colleagues suggests that the total number of activity sessions is particularly significant for the development of motor functions, while the intensity and the duration are not relevant parameters (Bremer, et al., 2015) .

Instead, Ketcheson and collaborators argue that different skills have different inter-critical developmental times: a significant increase in locomotor skills occurs in the first 4 weeks of intervention, whereas one must wait a longer period (4-8 weeks) to see significant improvements in object control (Ketcheson, et al., 2017) .

Regarding the proposal presentation, it emerges that the use of visual material instead of the verbal one promotes a simpler acquisition of new motor schemes. On the contrary, the model mediating the proposals (video, person, robot or brother) is not so relevant for the final result. (Ruggeri, et al., 2020).

In conclusion, performing physical activity produces benefits over the motor domain of autistic children and good motor functioning facilitates autistic individuals in several adaptive functions ranging from socialisation, play, and daily autonomies (Ketcheson, et al., 2017) . However, better defined protocols are needed to increase the level of evidence for this approach, to optimise the timing of the intervention according to the purposes, and to construct motor interventions tailored to specific aspects.

\section{Motor on behaviour}

One of the central features of autism spectrum disorder is behavioural impairment (American Psychiatric Association, 2013) . To address this, multiple intervention methodologies have been designed over time, most of which require a high degree of training and intensive treatments to produce significant results (Bremer, et al., 2016).

4 studies out of 10 focused also on a behavioural outcome following motor intervention and in particular on the reduction of stereotyped behaviour.

Although there is no unanimous agreement, most of the articles report a reduction in stereotypies following motor intervention.

Among the articles which do not find a significant result, for example the study by Oriel and colleagues, included in the meta-analysis by Ferreira (Oriel, et al., 2011) it is important to underline the fact that the length of the intervention is probably insufficient.

Also in the Huang search the heterogeneity of the results is linked to the different methodologies used in the various studies, which do not always make them directly comparable (Huang, et al., 2020).

This lack of methodological homogeneity is also reflected in the time frame. Successful interventions range from 8 to 48 weeks, with a frequency of 1 to 3 days per week and a single session lasting between 15 and 90 minutes.

However, there appears to be an inversely proportional relationship between treatment intensity and the number of stereotypies. (Ferreira, et al., 2019) .

Although there are also studies that support the opposite view, quiet aerobic activity appears to reduce stereotypies considerably. (Nazemzadegan, et al., 2016). However, a certain degree of activity seems to be necessary: running for 15 minutes can generate a change in stereotypes in the short term, whereas walking for the same amount of time cannot. (Bremer, et al., 2016).

The effects of the intervention last from 40 to 120 minutes after the activity, but data on time aspects and especially follow-up data are poorly considered.

To sum up, beyond the type of activity practiced (martial arts, aerobics, horse riding etc.), physical activity in autistic children can be helpful in the treatment of stereotyped behaviour.

This aspect becomes particularly relevant when stereotypies are very intrusive, as they have significant impact on the social environment and/or interfere with learning of the autistic child (Nazemzadegan, et al., 2016).

\section{Motor over cognitive}

In recent years, studies have supported an association between aerobic activity and increased cognitive performance, as physical activity also increases and 
modifies metabolism in the brain (Khan \& Hillman, 2014).

This evidence is particularly interesting to explore in autistic subjects, where the presence of deficits in executive functions is described. (Russo, et al., 2007). . Only one study, among those included in this review, tries to answer this question. Specifically, through a randomised-controlled trial, this experimental work investigates the effects of physical activity on executive functions: inhibition and working memory in children with autism.

The results show that physical activity produces a significant improvement in inhibition function, whereas the data do not reach the significance threshold for working memory (Tse, et al., 2019).

In the light of this, physical exercise alone, as a pure act that increases the metabolism, does not seem to be sufficient to create a permanent and significant change in executive functions.

Indeed, in the study the improvement in inhibition function seems to be linked to the type of exercises, which require fine control of the motor scheme, inhibiting all other movements (unnecessary or incorrect), in order to correctly complete the exercise (e.g. shooting a basket).

Instead, the simplicity of the instructions probably did not stimulate the working memory enough to obtain a significant improvement (Tse, et al., 2019). Further studies are needed to confirm these assumptions.

In relation to the highlighted improvement a motor intervention of 24 sessions ( 45 minutes each), spread over 12 weeks, seems to contribute to an increase of the inhibitory control skills of children with autism.

\section{Motor on socio-communicative}

Persistent social and communication difficulties are one of the two key aspects characterizing autism (American Psychiatric Association, 2013), so much that the majority of rehabilitation and educational interventions for autistic children are always directed and focused on promoting the social domain of the individuals involved (Zhao \& Chen, 2018), (Ketcheson, et al., 2017) .

More than half of the studies included in this review, indeed, consider the effects of their own motor intervention on the social and communication skills.

Overall, the results suggest that a motor intervention has a significant and positive impact on socio-communicative development and that this improvement can be linked to two essential determinants.

In group motor activities, children with autism find opportunities to experience social interaction that is not necessarily mediated by verbal language (Huang, et al., 2020).

Having a large and robust motor repertoire makes it easier for children to explore the environment and relate to it (Ketcheson, et al., 2017).

In addition, the review also shows that a well-structured motor programme (same group, same activities and same instructor) seems to give children the degree of stability needed to open up to others (Zhao \& Chen, 2018) .

Indeed, this approach leads to lower times of solitary play (Ketcheson, et al., 2017), more communicative exchanges and an increase in eye contact (Zhao \& Chen, 2018).

To achieve these improvements, motor interventions should be carried out in groups and last at least 12 weeks (twice a week with a minimum duration of 24 minutes per session).

It is also stated at a methodological level that it is useful to mark out the activities, proposing interactive exchanges between peers and using every play opportunity to relate with others in an ecological manner (Zhao \& Chen, 2018).

The results of the review thus seem to confirm that a group motor intervention can be a valid possibility to promote the development of social and communication skills in autism.

Only one of the studies analysed did not show any significant improvement, namely the pilot study by Bremer and colleagues in 2015, which involved a low number of participants (9) and few intervention sessions (12).

The centrality of sensorimotor experience, as a prerequisite and developmental factor to be interested in the world of things and people, is emphasised, confirming its highly adaptive value also as a tool for promoting the development of the deficient functions of children with autism.

\section{Motor and other}

Motor intervention in children with autism leads to several results:

- Improve their metabolic profile (Toscano, et al., 2018);

- Reduce typical autism traits (Huang, et al., 2020) , (Zhao \& Chen, 2018), (Toscano, et al., 2018);

- Increase sleep quality and duration (Tse, et al., 2019);

- Promote a better perception of quality of life in the parents of these children (Toscano, et al., 2018) ;

For all these reasons, the intervention must be personalised, adapted and modified according to specific needs, while maintaining its general motor nature.

\section{CONCLUSIONS}

In the light of the data that have emerged, proposing a motor pathway or the practice of physical activity/ sport to a child with autism is certainly a resource in the intervention project, especially because of the multiple benefits showed in the study.

Although further studies are needed to better define the methodologies and implications of this type of intervention, the data presented in this review clearly show the potential of this route.

The research was carried out on the idea that a global approach is needed to promote the neurodevelopment of autistic individuals, because the various domains constantly interface and influence each other, and a change in one area has a knock-on effect on the others.

According to this perspective, the Developmental Neuro and Psychomotor Therapist (TNPEE) assumes the role of a Developmental Therapist who proposes a rehabilitation intervention through an integrated view instead of focusing on a single competence or function.

This figure, indeed, finds its natural and direct collocation in these data, because by definition and modality of its intervention it matches this fascinating perspective. Considering the reciprocal relationships between the different functions, in a developmental perspective and in relation to the characteristics of 
a pathological development, is certainly a complex challenge. This complexity reflects the system within which rehabilitation in developmental age moves: the human mind and neurodevelopmental disorders.

Therefore, although for now, we are still far from understanding all aspects of correlation between motor activity and autism. Nowadays, as therapists we can integrate some of the evidence described in this review in our practice, considering the motor intervention not only from a mere motor point of view.

As professionals we could suggest families to encourage children to practice sport activities, given its positive effects in relation to weight control and the regularisation of sleep patterns, but also on social skills, as a proactive experience that allows children to connect with the environment and others.

The review does not provide solutions, but it does offer suggestions for improvements in professional practice, which may be helpful, especially to the young patient, to significantly affect the natural history of his or her disorder.

More precise data, better defined methodologies, follow-up studies and well-structured experimental designs are needed to build a highly effective, reliable motor intervention that produces the greatest possible number of positive effects on children with autism. Meanwhile, we also need an open mind to research, careful to seize any new evidence to improve our everyday practice with children.

\section{REFERENCES}

1. American Psychiatric Association, (2013). Diagnostic and Statistical Manual of Mental Disorders. 5th ed. Arlington,TX: American Psychiatric Publishing.

2. Bremer, E., Balogh, R. \& Lloyd, M., (2015). Effectiveness of a fundamental motor skill intervention for 4-yearold children with autism spectrum disorder: A pilot study.. Autism, 19(8), pp. 980-991.

3. Bremer, E., Crozier, M. \& Lloyd, M., (2016). A systematic review of the behavioural outcomes following exercise interventions for children and youth with autism spectrum disorder. Autism, 20(8), p. 899-915.

4. Casartelli, L. \& Chiamulera, C., (2016). The motor way: Clinical implications of understanding and shaping actions with the motor system in autism and drug addiction. Cognitive Affective Behavioural Neuroscience, Volume 16, p. 191-206.

5. Casartelli, L. \& Molteni, M., (2014). Where there is a goal, there is a way: What, why and how the parieto-frontal mirror network can mediate imitative behaviours. Neuroscience \& Biobehavioral Reviews, Volume 47, pp. 177193.

6. Casartelli, L., Molteni, M. \& Ronconi, L., (2016). So close yet so far: Motor anomalies impacting on social functioning in autism spectrum disorder. Neuroscience \& Biobehavioral Reviews, Volume 63, pp. 98-105.

7. Ferreira, J. et al., (2019). Effects of Physical Exercise on the Stereotyped Behavior of Children with Autism Spectrum Disorders. Medicine, 55(10), p. E685.

8. Gallese, V., Rochat, M., Cossu, G. \& Sinigaglia, C., (2009). Motor cognition and its role in the phylogeny and ontogeny of action understanding. Developmental Psychology, Volume 45, p. 103-113.

9. Healy, S., Nacario, A., Braithwaite, R. \& Hopper, C., (2018). The effect of physical activity interventions on youth with autism spectrum disorder: A meta-analysis. Autism research, 11(6), pp. 818-833.

10. Hilton, C. et al., (2012). Motor impairment in sibling pairs concordant and discordant for autism spectrum disorders. Autism, 16(4), pp. 430-441.

11. Huang, J., Du, C., Liu, J. \& Tan, G., (2020). Meta-Analysis on Intervention Effects of Physical Activities on Children and Adolescents with Autism. International Journal of Environmental Research and Public Health, 17(6), p. E1950.

12. Ketcheson, L., Hauck, J. \& Ulrich, D., (2017). The effects of an early motor skill intervention on motor skills, levels of physical activity, and socialization in young children with autism spectrum disorder: A pilot study. $A u$ tism, 21(4), pp. 481-492.

13. Khan, N. \& Hillman, C., (2014). The relationship of childhood physical activity and aerobic fitness to brain function and cognition: a review. Pediatric Exercise Science, 26(2), p. 138-146.

14. Kramer, A. \& Erickson, K., (2007). Capitalizing on cortical plasticity: influence of physical activity on cognition and brain function. Trends in cognitive sciences, 11(8), pp. 342-348.

15. Lai, M. et al., (2020). Evidence-based support for autistic people across the lifespan: maximising potential, minimising barriers, and optimising the person-environment fit. The Lancet Neurology, 19(5), pp. 434-451.

16. Lai, M.-C., V Lombardo, M. \& Baron-Cohen, S., (2014). Autism. The Lancet, Volume 383, pp. 896-910.

17. McCoy, S., Jakicic, J. \& Gibbs, B., (2016). Comparison of Obesity, Physical Activity, and Sedentary Behaviors Between Adolescents With Autism Spectrum Disorders and Without. Journal of Autism Development Disorder, 46(7), pp. 2317-2326.

18. Nazemzadegan, G., Babadi, A., Zeinali, Z. \& Kakavandi, K., (2016). Effectiveness of Ball Exercises on Reduction of Stereotypic Behavior of Children with Autism Spectrum Disorder with High Performance. Iranian rehabilitation journal, Volume 14, p. 121-126. 
19. Oriel, K. G. C., Peckus, R. \& Semon, A., (2011). The Effects of Aerobic Exercise on Academic Engagement in Young Children With Autism Spectrum Disorder. Pediatric Physic Therapy, 3(2), p. 187-193.

20. Pan, C. et al., (2017). The impacts of physical activity intervention on physical and cognitive outcomes in children with autism spectrum disorder. Autism, 21(2), p. 190-202.

21. Rogers, S. J. et al., (2014). Autism Treatment in the First Year of Life: A Pilot Study of Infant Start, a ParentImplemented Intervention for Symptomatic Infants. Journal of autism and developmental disorders, 44(12), p. 2981-2995.

22. Ruggeri, A., Dancel, A., Johnson, R. \& Sargent, B., (2020). The effect of motor and physical activity intervention on motor outcomes of children with autism spectrum disorder: A systematic review. Autism, 24(3), pp. 544-568.

23. Russo, N. et al., (2007). Deconstructing executive deficits among persons with autism: implications for cognitive neuroscience. Brain and cognition, 65(1), pp. 77-86.

24. Sam, K.-L., Chow, B.-C. \& Tong, K.-K.,(2015). Effectiveness of Exercise-Based Interventions for Children with Autism: A Systematic Review and Meta-Analysis. International Journal of Learning and Teaching, Volume 1, pp. 98-103.

25. Sanchack, K., Thomas \& CA, (2016). Autism Spectrum Disorder: Primary Care Principles. Am Fam Physician, 94(12), pp. 972-979.

26. Tan, B., Pooley, J. \& Speelman, C., (2016). A Meta-Analytic Review of the Efficacy of Physical Exercise Interventions on Cognition in Individuals with Autism Spectrum Disorder and ADHD. Journal of autism developmental disorder, 46(9), pp. 3126-3143.

27. Toscano, C., Carvalho, H. \& Ferreira, J., (2018). Exercise Effects for Children With Autism Spectrum Disorder: Metabolic Health, Autistic Traits, and Quality of Life. Perceptual and motor skills, 125(1), pp. 126-146.

28. Tse, C. et al., (2019). Examining the impact of physical activity on sleep quality and executive functions in children with autism spectrum disorder: A randomized controlled trial. Autism, 23(7), pp. 1699-1710.

29. World Health Organization, (2010). Global Recommendations on Physical Activity for Health. Geneva: WHO Press.

30. Zhao, M. \& Chen, S., (2018). The Effects of Structured Physical Activity Program on Social Interaction and Communication for Children with Autism. BioMed research international, eCollection 2018(1825046). 